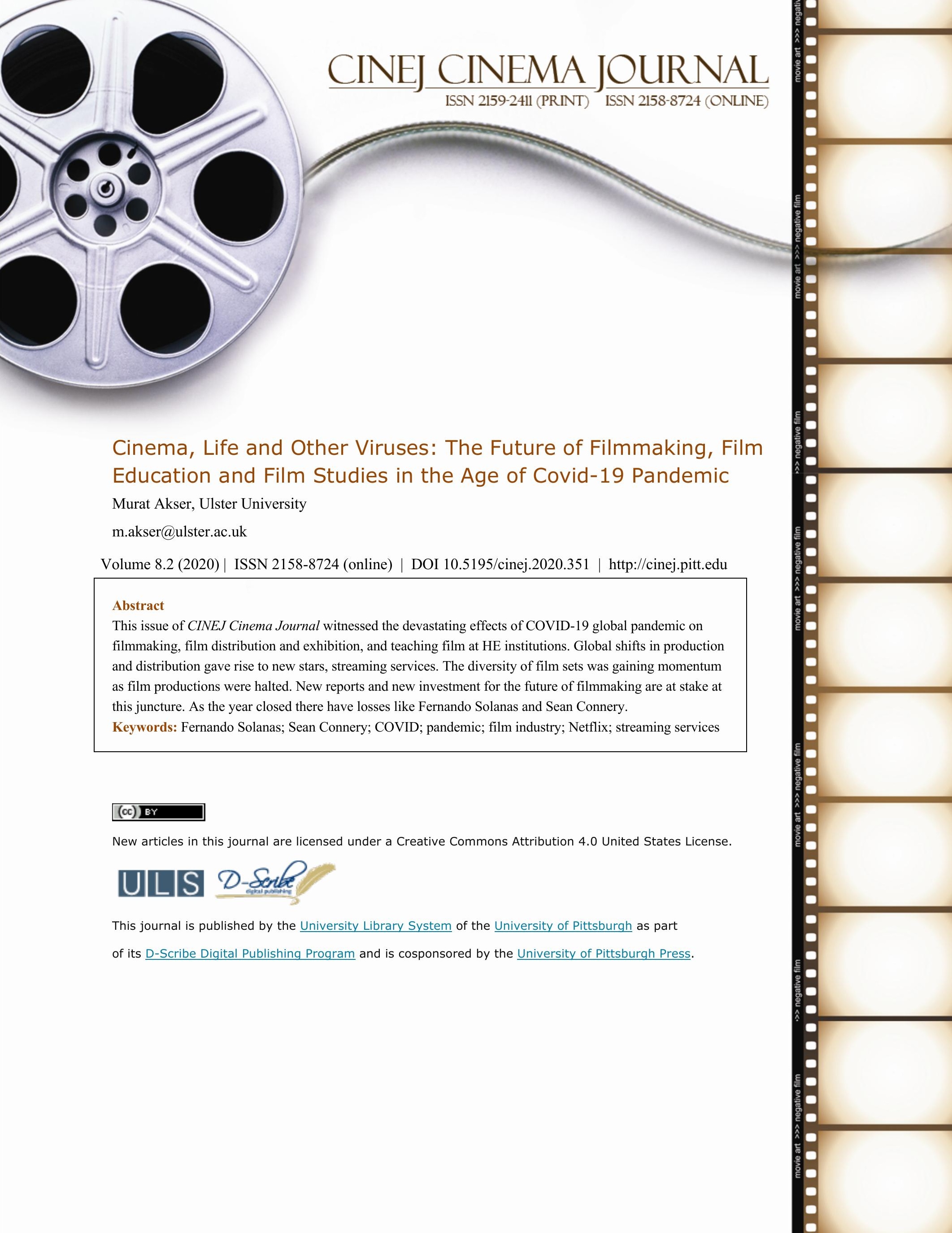




\section{Cinema, Life and Other Viruses: The Future of Filmmaking, Film Education and Film Studies in the Age of Covid-19 Pandemic}

\section{Murat Akser}

Pre COVID-19 pandemic situation saw the rise of streaming services like Netflix, Amazon Prime, Apple TV+ and Disney+. The blockbuster films series of MCU and DCU were ruling supreme with their hundreds of million dollars of budgets and billions of dollars of worldwide box office revenue. The pandemic halted all that. Most countries shut down film productions, film theatres and universities where new generation of filmmakers were trained. These developments came just after the bright future promised in academic studies and reports in the UK and Ireland on the future of cinema (Stolz, A., Atkinson, S. A., \& Kennedy, 2020). Both reports acknowledged the impact of screen production on economy as a whole. With the pandemic this whole ecology collapsed. Major film released were delayed. The film exhibition industry started waiting for the Tenet phenomenon, whereby the release of an expected blockbuster, like this Nolan film, could revive the ailing film industry. Tenet's release was delayed a couple of times and the final release did not satisfy the theatre owners as the public fears of keeping close distance with strangers in closed spaces proved to be a negative effect for audiences. The delay announcement of the release of the next Bond film No Time to Die, led British theatre owners to declare bankruptcy. Still there is some hope for future releases of Hollywood films like Wonder Woman 1984, Dune, Black Widow, and Top Gun Maverick which are all delayed until 2021. Most of the mid-range films were released through the streaming platforms like Netflix and Amazon Prime, who are themselves now global film studios with access to entire world markets. They are creating a new monopoly on not only production and distribution but also on storytelling canon and conventions (Van Esler, 2020) 
Film production was also negatively affected. There are now new protocols in place to keep the actors and crews safe. Yet even with the best of intentions new reports indicate that the virus is spreading across the globe on films sets too. As the UK was inching toward Brexit, it left the European Union's Media program casting doubts on how international film coproduction could be financed by the UK producers. There are positive developments like Belfast city deal to create film studios and the establishment of VR studio/lab by Declan Keeney of Ulster University. Such developments are a beacon of hope for the future of film industry.

As one observer noted film festivals refused to "go silently into the night" (Salti, 2020). Many film festivals had to be cancelled or simply went online (Zielinski, 2020). Festival circuit had gained enormous power through the art and independent filmmaking circles when the pandemic hit. Toronto, Berlin, Cannes had become epicentres of not only finding new talent but also crafting the coming of that talent. Venice had a controlled opening, Cannes went virtual, Berlin was saved in 2020 and plans to keep the same profile in 2021.

Film sets were already rocked positively by MeToo and Black Lives Matter movements' impact on diverse and inclusive recruitment regime sett. CBS led series Star Trek Discovery are among those who actively train and hire diverse talent: women and ethnic minorities. How much negatively this new diversity be affected by the pandemic is still uncertain (Eikhof, 2020). Covid 19 outbreak also exposed the precarity on film sets (Comunian, R. \& L. England, 2020).

Teaching filmmaking has proved to be a challenge as the practice-based classes were cancelled, shortened, or delayed until 2021. The zoom factor, the constant migraine inducing teaching learning online from homes proved to be a distressing factor for both the lecturers and the students. The need to access online films for educational purposes for free would be the new frontier to explore for policymakers in the higher education sector. 
On the film studies side there have been welcome developments. eBooks became more popular as publishers could not access distributors and stores for hardback and soft back book sales. New global screens from brill has been a welcome development. There are refreshing new scholarly work from academics around the world. (Özdüzen, 2019; Erensoy, 2020; Cengiz 2020; Baykan, 2020; Taş Öz, P. and Erensoy, Ş., 2020; Strohmaier, 2021).

And then there were losses. The last issue of CINEJ witnessed the passing away of two important film theorists Wollen and Elsaesser (Akser, 2020; Przylipiak, 2019). With this issue we lost Fernando Solanas, one of the founders of third cinema, a great filmmaker and cultural icon for many around the world. The original James Bond, Sean Connery also left us at the age 90. The importance of his work and Bond as a cultural phenomenon is still relevant in recent studies (Behlil, M., Prado, I. M. S., \& Verheul, J., 2020). The future of filmmaking will be uncertain for a brief period. There those who think that the future may be in microbudget feature filmmaking (McBratney, S., Minichiello, M., \& Roxburgh, M., 2020) and solidarity-based talent development across borders (Hjort, 2019).

This issue of CINEJ was prepared under COVID lockdown. We had high quality submissions that lead to the creation of rich and diverse content. Meghna Sapui's "Billions in Debt and Still Surviving": Curing the Female Shopper in Confessions of a Shopaholic" analyses P.J. Hogan's Confessions of a Shopaholic (2009) in three sections (Sapui, 2020). In the first section, Sapui studies how the film maps shopping as an illness that needs to be cured onto the body of its female heroine. She argues that is done by portraying her as a patient suffering from Compulsive Buying Disorder (CBD). In the second part, Sapui traces how Confessions necessitates the cure of the female shopper, given its background of the Great Recession and how 
this holds generic significance for the romantic comedy. She then concludes by charting the heroine's cure in group therapy as predicated upon the principle of the Foucauldian confession and how this then resolves the narrative as, what Diane Negra calls, one of "adjusted ambitions."

Hoda Shabrang takes a look at a now cult horror film through her "Shattered Identity of Immigrant Artist and Creation of Art in a Hybridized Space: The Case Study of A Girl Walks Home Alone at Night" article (Shabrang, 2020). In this article, Shabrang first discusses the "paradox of assimilation and difference" and its consequences and then the film A Girl Walks Home Alone at Night by Ana Lily Amanpour. She argues how the main character's shattered identity as an immigrant is represented in her art. The film, she further argues, is an amalgamation of different signs from both cultures. These signs are not completely related to host culture (American) or local culture (Iranian). Although this impossible situation seems very painful at the first glance, it is beneficial for immigrant artist. In this hybridized space, the director creates a kind of art which is very innovative and unique, because she is not forced to follow the cliché styles which those cultures are dictating her.

Michael Fuchs' "Crushing Life in the Anthropocene? Destroying Simulated "Nature" in The Cabin in the Woods" looks at the horror film The Cabin in the Woods (2011) as a highly selfreflexive movie that is aware of its generic roots (Fuchs, 2020). Fuchs argues that the film struggles with the meaning of "the woods" in the horror genre. Cabin's central twist in this respect is that the titular "woods" are not untamed nature, but rather a place of artifice. Cabin's woods are not uncanny because they are far removed from "civilization," but rather exactly because they are part of it. The film's emphasis on the artificiality of nature suggests that the concept of "nature" is exactly that—a concept, a cultural construct, loaded with meaning. 
Tolga Ekinci (2020) in his "“Youtuber Movies" From New Media to the Cinema" article "YouTuber movies" are examined via genre criticism as method. Coşkun Liktor in "Wild Pear Trees, Patrimonial Legacies: Father-Son Relationship in Nuri Bilge Ceylan's The Wild Pear Tree" Tree analyzes the father-son relationship in Nuri Bilge Ceylan's latest film The Wild Pear Tree (2018), which tells the story of a son who desires a life as unlike his father's narrow, provincial life as possible, only to find himself following in his father's footsteps almost against his will (Liktor, 2020). Drawing upon Freudian and Lacanian psychoanalysis, Liktor examines the film as an oedipal drama that portrays the predicament of a son who grapples with an ineffectual, humiliated father that fails to embody the paternal function.

Hasan Yüksel in his "The Urbanization of Labor and Its Struggle for Unionism in Turkish Cinema" investigates the emergence of labor and its struggle for unionism in Turkey in parallel to the process of urbanization on the basis of a particular Turkish employee film named after The Blood Money (Diyet). Yüksel claims that labor has become a labor and unionism has converted into a professional and institutional background in the aftermath of the announcement of Republican period despite some ups and downs. In the 1950s, the capital was urbanized which was the case for labor in the 1960s and hereafter (Yüksel, 2020).

In Adiba Asraf's "Emerging Discourses, Changing Perspectives: Iraq in Oscar Documentary Films" shows how documentaries are projecting scepticism and sarcasm of Iraqi people due to volatile, uncertain complex, and ambiguous (VUCA) conditions (Ashraf, 2020). The sample of this study consists of Oscar-winning and Oscar-nominated documentary films from 2003 to 2011 with a total of 45 films. Through the criterion sampling, Ashraf selects four films that depict Iraq and all the four was nominated for Oscar that includes: Iraq in Fragments (2006-Nomination); My 
Country My Country (2006-N); No End in Sight (2007-N); Operation Homecoming: Writing the Wartime Experience (2007-N). To explore Iraqi people's perspectives, Ashraf further applies further sampling and selects two documentaries depicting entanglement of religion and politics in Iraq from Iraqi people's perspective.

Shiva Khalili Kolahian's "An analytical study of the ritual ceremonies in Iranian performing arts, a case study of Travellers" explores the standing of rites and ritual arts in Travellers and analyzes its atmosphere regarding to performing rituals. The researcher proposes that the film's scene design changes as the script process, so that the application of elements such as light and color, and their intensity and reduction in different mental conditions, from pleasure to mourning, has been considered wisely, and the atmosphere has a dramatic impact on the audience in different scenes. The lighting and the coloring of the scenes in the movie, indicates a tribute to beliefs and faith in rites and ritual arts.

Minakshi Dutta's "A Reading of Bhabendra Nath Saikia's Films from Feminist Lens" explores the questions related to women's representation by taking the films of Assamese director Dr. Bhabendra Nath Saikia as reference. The article also covers a historical overview of the representation of women in Indian cinema and Assamese cinema.

Aybike Serttaş's article "Transformation of Love in the Digital Age: The film Her and Reaching God through the love in the Perspective of Sufism" analyses the Spike Jonze film Her using semiotic analysis (Serttaş 2020). Mentioning the differences between love simulacra created in social media and love in real life, the semiotic analysis of the film Her is carried out with the indicators that match the criteria to find God through love in Sufism. In Abdorreza Naser Moghadasi's "Evaluation of Neurocinema as An Introduction to an Interdisciplinary 
Science" looks at neurocinema as way of investigating film whose content includes patients' neurological and psychiatric problems (Naser Moghasai 2020).

Milad Minakar and Amir Hossein Chitsazian's "The Study of Rubaiyat attributed to Khayyam in Movies" studies filmic coverage of Hakim Omar Khayyam's Rubaiyat in English and Persian language feature and non-biographical films excluding, biographical films depicting factual or imaginary life of Khayyam or any serials, TV productions, documentaries, nonEnglish, non- Persian films. The aim is to expound any relationships between the films and Rubaiyat (Minakar and Chitsazian, 2020).

Mustafa Mahmoud Yousry Matbouly's "The Effects of Film Illumination Hues - An Exploration Study" is an attempt to investigate the ability of different colors used in cinematic lighting designs to affect audience's impressions towards the appearance and mood of film characters (Matbouly 2020). The study critically appraises existing cinematic lighting techniques and identified the two basic color groups (i.e., warm and cold colors) that should be examined in order to answer the research questions and formulate its conclusions. The study concludes that audience's perception of appearances and moods within cinematic images is linked, even in part, to different colors of lighting.

Selma Köksal Çekiç unearths a neglected director from Turkey in her "Antiochia As A Cinematic Space and Semir Aslanyürek as a Film Director From Antiochia". She looks at cinematic representation of Antiochia, a city with multiple identities, with a multi-cultural, long and deep historical background in Turkish director Semir Aslanyürek’s films (Köksal Çekiç, 2020). The article focuses on Aslanyürek's visual storytelling through his beloved city, his main 
characters and his main conflicts and themes in his films Şellale (2001), Pathto House (2006), 7 Yards (2009), Lal (2013), and Chaos (2018). This article bases its arguments on Aslanyürek's cinematic vision as multi-cultural and as a multi-disciplinary visual artist.

"In Transformation of Comedy with Streaming Services: The Case of Bartu Ben" Nisa Yildirim studies the comedy series Bartu Ben (It's me, Bartu) which is one of the original series of Turkish streaming service: Blu TV (Yıldırım, 2020). The study aims to interpret the differences provided by streaming services which contributes to the transformation of comedy genre. Before studying the case, comedy genre in Turkish cinema and television will be analyzed briefly.

Finally, in "A Moebial Ride through Polanski’s Repulsion" Defne Tüzün examines Roman Polanski's film Repulsion from a psychoanalytic perspective by attending Julia Kristeva's notion of abjection (Tüzün 2020). This article deals primarily with two main focal points. First, it focuses on the film's portrayal of the protagonist, Carole's abjection, her problem of nondifferentiation, as evidenced by her relation to the maternal body and to corporeality. Secondly, the article investigates how the film positions its viewers with regard to Carole. It questions how Repulsion impels its spectators to engage Carole with a similar non-differentiation by generating a complex web of ambiguities with regard to the differentiation between external/internal, objective/subjective and reality/fantasy.

\section{BIBLIOGRAPHY}

Akser, M. (2020). Remembering Thomas Elsaesser and Peter Wollen. CINEJ Cinema Journal, $8(1), 1-13$.

Asraf, A. (2020). Emerging Discourses, Changing Perspectives: Iraq in Oscar Documentary 
Films. CINEJ Cinema Journal. 8(2), 195-216.

Ayanbadejo, M. How has COVID-19 impacted the evolution of cinemas?. General Management in Lockdown, 1-6. Pembroke College, Oxford.

https://www.pmb.ox.ac.uk/sites/default/files/em_student_project_tt20.docx.pdf

Baykan, B. (2020) Body without Organs as Pure Potentiality in Patricia Piccinini's Sculptural Installations in Przedpełski, R. and S. E. Wilmer eds. (2020). Deleuze, Guattari and the Art of Multiplicity. Edinburgh: Edinburgh University Press.

Barton, R. and D. Murphy (2019). Ecologies of Cultural Production Career construction in Irish film, TV drama and theatre. Report for the Creative Ireland Programme. https:/www.creativeireland.gov.ie/app/uploads/2020/03/ECP.pdf

Behlil, M., Prado, I. M. S., \& Verheul, J. (2020). The Dead Are Alive: The Exotic Non-Place of the Bondian Runaway Production. In Verheul (Ed.) The Cultural Life of James Bond, (81102). Amsterdam University Press.

Cengiz, E. P. (2020). Women's Rights and Gender Equality in Turkey: Cinema Has Split the Girl's Soul Into Pieces: Scrutinizing Representations of Women in Films From Turkey. International Journal of Communication 14, 5482-5498.

Comunian, R. \& L. England (2020) Creative and cultural work without filters: Covid-19 and exposed precarity in the creative economy, Cultural Trends, 29(2),112-128.

Dutta, M. (2020). A Reading of Bhabendra Nath Saikia's Films from Feminist Lens. CINEJ Cinema Journal. 8(2), 247-274.

Eikhof, D. R. (2020). COVID-19, inclusion and workforce diversity in the cultural economy: what now, what next?. Cultural Trends, 29(3), 234-250. 
Ekinci, T. (2020). "Youtuber Movies" From New Media to the Cinema. CINEJ Cinema Journal. $8(2), 94-118$.

Erensoy, Ş.F. (2020). The Technological Turn of the Femme Fatale: The Fembot and Alternative Fates. In: Sezen D., Çiçekoğlu F., Tunç A., Thwaites Diken E. (eds) Female Agencies and Subjectivities in Film and Television. Palgrave Macmillan.

Fuchs, M. (2020). Crushing Life in the Anthropocene? Destroying Simulated "Nature" in The Cabin in the Woods. CINEJ Cinema Journal. 8(2), 62-93.

Hjort, M. (2019) The ontological transnationalism of the filmmaker: solidarity-based talent development across borders, Transnational Screens, 10(1), 53-68.

Khalili Kolahian, S. (2020). An analytical study of the ritual ceremonies in Iranian performing arts, a case study of Travellers. CINEJ Cinema Journal. 8(2), 217-246.

Köksal Çekiç, S. (2020). Antiochia As A Cinematic Space and Semir Aslanyürek as a Film Director From Antiochia. CINEJ Cinema Journal, 8(2), 377-402.

Liktor, C. (2020). Wild Pear Trees, Patrimonial Legacies: Father-Son Relationship in Nuri Bilge Ceylan's The Wild Pear Tree. CINEJ Cinema Journal, 8(2), 119-149.

Matbouly, M.M.Y. (2020). The Effects of Film Illumination Hues - An Exploration Study. CINEJ Cinema Journal, 8(2), 353-376.

McBratney, S., Minichiello, M., \& Roxburgh, M. (2020). 'Don’t Read This on a Plane': a case study in microbudget feature filmmaking. Studies in Australasian Cinema, 14(2), 144-159.

Naser Moghadasi, A. (2020). Evaluation of Neurocinema as An Introduction to an Interdisciplinary Science. CINEJ Cinema Journal, 8(2), 307-323. 
Nhamo G., Dube K., Chikodzi D. (2020) Implications of COVID-19 on Gaming, Leisure and Entertainment Industry. In: Counting the Cost of COVID-19 on the Global Tourism Industry. Springer.

Minakar, M. and A. H. Chitsazian (2020). The Study of Rubaiyat attributed to Khayyam in Movies. CINEJ Cinema Journal, 8(2), 324-352.

Mingant, N. A. (2013). 'Not A Terrorist': The Representational Alternative of Reality TV in AllAmerican Muslim. CINEJ Cinema Journal, 3(1), 4-27.

Özyilmaz, Ö. (2018). Responses of The Film Industry and Audiences to The Introduction of Sound Cinema in Turkey (1929-1933) Music, Sound \& the Moving Image, 12(2): 241-257.

Przylipiak, M. (2019). Thomas Elsaesser and film studies. Panoptikum, (22), 10-28.

Serttaş, A. (2020). Transformation of Love in the Digital Age: The film Her and Reaching God through the love in the Perspective of Sufism. CINEJ Cinema Journal. 8(2), 275-306.

Salti, R. (2020). Do Not Go Gentle into That Good Night: Film Festivals, Pandemic, Aftermath. Film Quarterly, 74(1), 88-96.

Sapui, M. (2020) Billions in Debt and Still Surviving": Curing the Female Shopper in Confessions of a Shopaholic. CINEJ Cinema Journal. 8(2), 14-44.

Shabrang, H. (2020). Shattered Identity of Immigrant Artist and Creation of Art in a Hybridized Space: The Case Study of A Girl Walks Home Alone at Night. CINEJ Cinema Journal. 8(2), 45-44.

Stolz, A., Atkinson, S. A., \& Kennedy, H. W. (2020, Mar 19). The Future of Film Report 2020. https://doi.org/10.18742/pub01-020 
Strohmaier, A. (2021) On the Re-Configurations of Cinematic Media-Spaces: From Diaspora Film to Postdiaspora Film. In: Ouaissa R., Pannewick F., Strohmaier A. (eds) ReConfigurations. Politik und Gesellschaft des Nahen Ostens. Springer VS, Wiesbaden. https://doi.org/10.1007/978-3-658-31160-5_14

Talu, Y. (2019) The Big Screen: The Wild Pear Tree Film Comment. 55(1): 68-69.

Taş Öz, P. and Erensoy, Ş. (2020). Looking At Robert Altman's Cinema Through An AntiHollywood Perspective . OPUS Uluslararası Toplum Araştırmaları Dergisi , 16 (31), 3837-3852 . DOI: 10.26466/opus.811929

Tüzün, D. (2020). A Moebial Ride through Polanski’s Repulsion. CINEJ Cinema Journal, 8(2), 326-356.

Van Esler, M. (2020). Reproducing Television Canons: Streaming Services and the Legacy of Linear TV. The Journal of Popular Culture. 53(4), 946-966.

Verheul, J. (Ed.). (2020). The Cultural Life of James Bond: Specters of 007. Amsterdam: Amsterdam University Press.

Wibowo, T. O. (2019). Understanding movie streaming websites in Indonesia as unlimited movie access in the digital era. Jurnal Komunikasi: Malaysian Journal of Communication, 35(2), 247-259.

Y1dirım, Nisa (2020). Transformation of Comedy with Streaming Services: The Case of Bartu Ben. CINEJ Cinema Journal, 8(2), 403-425.

Yüksel, H. (2020) The Urbanization of Labor and Its Struggle for Unionism in Turkish Cinema. CINEJ Cinema Journal. 8(2), 150-194.

Zielinski, G. (2020). In-Sync or Not. Ger Zielinski's Reflections on the Proliferation of Online Film Festivals during the COVID-19 Global Pandemic. In: Open-Media-Studies-Blog der Zeitschrift für Medienwissenschaft, online, 5. Oktober 2020, https://www.zfmedienwissenschaft.de/node/1586. 